\title{
Genetic Variation in Native Populations of the Laurel Wilt Pathogen, Raffaelea lauricola, in Taiwan and Japan and the Introduced Population in the United States
}

Caroline E. Wuest and Thomas C. Harrington, Department of Plant Pathology, Iowa State University, Ames 50011; Stephen W. Fraedrich, Southern Research Station, USDA Forest Service, Athens, GA 30605; Hye-Young Yun, Department of Agricultural Biotechnology, Seoul National University, Seoul, Korea 08826; and Sheng-Shan Lu, Division of Forest Protection, Taiwan Forestry Research Institute, Taipei 10066, Taiwan

\begin{abstract}
Laurel wilt is a vascular wilt disease caused by Raffaelea lauricola, a mycangial symbiont of an ambrosia beetle, Xyleborus glabratus. The fungus and vector are native to Asia but were apparently introduced to the Savannah, GA, area 15 or more years ago. Laurel wilt has caused widespread mortality on redbay (Persea borbonia) and other members of the Lauraceae in the southeastern United States, and the pathogen and vector have spread as far as Texas. Although believed to be a single introduction, there has been no extensive study on genetic variation of $R$. lauricola populations that would suggest a genetic bottleneck in the United States. Ten isolates of $R$. lauricola from Japan, 55 from Taiwan, and 125 from the United States were analyzed with microsatellite and 28S rDNA markers,

and with primers developed for two mating-type genes. The new primers identified isolates as either MAT1 or MAT2 mating types in roughly equal proportions in Taiwan and Japan, where there was also high genetic diversity within populations based on all the markers, suggesting that these populations may have cryptic sex. Aside from a local population near Savannah and a single isolate in Alabama that had unique microsatellite alleles, the U.S. population was genetically uniform and included only the MAT2 mating type, supporting the single introduction hypothesis. This study suggests the importance of preventing a second introduction of $R$. lauricola to the United States, which could introduce the opposite mating type and allow for genetic recombination.
\end{abstract}

Laurel wilt is a true vascular wilt disease caused by the ambrosia fungus Raffaelea lauricola T. C. Harr., Fraedrich, and Aghayeva, which is carried by its ambrosia beetle symbiont, Xyleborus glabratus Eichoff (Fraedrich et al. 2008; Harrington et al. 2008). Raffaelea is a common genus of saprophytic fungi symbiotically associated with ambrosia beetles (Harrington et al. 2010). R. lauricola is unique in that it is the only ambrosia fungus known to cause a vascular wilt. The vector was first detected in the United States in 2002 at Port Wentworth, GA, near Savannah (Rabaglia et al. 2006), where it and its symbiont may have been introduced in solid wood packaging material (Fraedrich et al. 2008). Laurel wilt was first discovered in the United States in 2004, when mortality of redbay (Persea borbonia) appeared in the lower coastal plains of South Carolina and Georgia, and in northeastern Florida in 2005 (Fraedrich et al. 2008). Since the first appearance of laurel wilt on redbay and sassafras (Sassafras albidum) in South Carolina, Georgia, and Florida, the disease has spread throughout the southeastern United States.

Initial reports in new states were on redbay [Mississippi (Riggins et al. 2010), North Carolina (Hughes et al. 2015), and Texas (Menard et al. 2016)] or on sassafras [Alabama (Bates et al. 2015), Louisiana (Fraedrich et al. 2015a), and Arkansas (Olatinwo et al. 2016)]. However, all tested American Lauraceae have been shown to be susceptible to laurel wilt in inoculation studies (Fraedrich et al. 2008, 2011; Hughes et al. 2013; Ploetz and Konkol 2013). The disease occurs on avocado ( $P$. americana), silk bay ( $P$. humilis), pondspice (Listsea aestivalis), and spicebush (Lindera benzoin), on the European bay laurel (Laurus nobilis), and on the Asian camphortree (Cinnamomum camphora) (Fraedrich et al. 2015b, 2016; Hughes et al. 2011, 2012, 2014; Mayfield et al. 2008; Smith et al. 2009a, 2009b). The laurel wilt epidemic is expected to eventually progress to Mexico, a country

Corresponding author: Tom Harrington; E-mail: tcharrin@ iastate.edu

Accepted for publication 30 November 2016.

This article is in the public domain and not copyrightable. It may be freely reprinted with customary crediting of the source. The American Phytopathological Society, 2017. rich with native Lauraceae and a large avocado crop industry (Ploetz et al. 2012).

The vector is native to Southeast Asia, most often associated with plant species in the family Lauraceae, and has been reported in India, Bangladesh, Myanmar, China, Japan, and Taiwan (Hulcr and Lou 2013; Rabaglia et al. 2006). $R$. lauricola was consistently isolated from X. glabratus in Japan and Taiwan (Harrington et al. 2011), and the pathogen and laurel wilt were recently detected on avocado in Myanmar (Ploetz et al. 2016). Raffaelea lauricola is the dominant mycangial symbiont of $X$. glabratus in both the United States and Asia (Campbell et al. 2016; Harrington and Fraedrich 2010; Harrington et al. 2010, 2011). The beetle has been reported to carry up to an estimated 30,000 CFU of $R$. lauricola in the paired oral mycangia of a single beetle, and the overflow of the mycangial growth inoculates the walls of the excavated tunnels in the woody xylem (Harrington and Fraedrich 2010). In both Asia and United States, it is believed that the vector inoculates healthy trees by boring into the xylem, but then aborting the attacks; brood galleries are excavated by later generations of beetles in the wilted branches and stems (Fraedrich et al. 2008, 2015b; Harrington and Fraedrich 2010; Harrington et al. 2011).

It has been assumed that there was a single introduction of the pathogen to the United States (Harrington et al. 2011), but the genetic variation in U.S. and Asian populations has not been extensively studied to test this hypothesis. Harrington et al. (2011) found that some isolates of $R$. lauricola from Japan and Taiwan have a base substitution in the D1/D2 region of the 28S rDNA (LSU) gene. Dreaden et al. (2014) developed two microsatellite markers that amplified trinucleotide repeat regions in the $R$. lauricola genome. The IFW microsatellite marker was monomorphic among U.S. isolates, as well as one isolate from Taiwan and another from Japan. The $\mathrm{CHK}$ microsatellite marker was polymorphic, detecting a second allele (a different number of TCT repeats) in a Japanese isolate (Dreaden et al. 2014).

To test the hypothesis that a single genotype of $R$. lauricola was introduced to the United States from Asia, we analyzed and compared the genetic diversity of Taiwan and Japan populations to that of the U.S. population. If the pathogen is native to Asia but introduced to the United States, we would expect much more diversity 
in Taiwan and Japan than in the United States. To see if the Asian populations may be reproducing sexually, PCR primers for matingtype genes of $R$. lauricola were developed and deployed as genetic markers.

\section{Materials and Methods}

Isolates and DNA extraction. Most of the Asian isolates of $R$. lauricola were from $X$. glabratus collected on sticky traps baited with manuka oil lures set out in Fushan, Lienhuachih, and Hsinhsien, Taiwan, in April-December 2009 and in Koshi, Japan, in September 2009 (Harrington et al. 2011). At each of the four sites, two or three sticky traps were in place during a collecting period, but beetles collected from the two or three traps were pooled for each sampling period. Dead beetles were shipped to Iowa, ground and dilution-plated on CSMA (1\% malt extract and $1.5 \%$ agar, amended with 200 ppm cycloheximide and $100 \mathrm{ppm}$ streptomycin sulfate after autoclaving).

Five additional isolates from Hsinhsien, Taiwan, were obtained in 2014 from a bolt cut from a dying Cinnamomum osmophloeum tree that was recently attacked by $X$. glabratus. Three isolates were obtained from three beetles excavated from the bolt using dilution plating, and two isolates were obtained by splitting the bolt and scraping ambrosial growth in a gallery with a flame-sterilized needle and streaking on CSMA.

A total of 125 isolates of $R$. lauricola were collected from 2005 to 2015 in the United States from sapwood of trees with laurel wilt or from adult female $X$. glabratus beetles. Seventeen of the isolates were from $X$. glabratus adults that were trapped in flight, most collected using Lindgren traps baited with manuka oil or cubeb oil (Harrington and Fraedrich 2010). Eighteen isolates were from $X$. glabratus adults reared from naturally infested trees or from bolts taken from healthy trees and baited with manuka oil: one from swampbay (Persea palustris), eight from redbay, seven from sassafras, one from avocado, and one from camphortree. Three isolates were from Xyleborinus saxesenii beetles excavated from a diseased pondspice bush, and one isolate was from a Xylosandrus crassiusculus beetle reared from a sassafras tree with laurel wilt. Isolations from symptomatic sapwood of diseased trees included 58 redbay trees, two Persea spp. trees, two avocado trees, 10 sassafras trees, three pondberry (Lindera melisifolia) bushes, three camphortrees, three pondspice bushes, and two spicebushes. In total, three isolates were collected from North Carolina, 32 from South Carolina, 55 from Georgia, 11 from Florida, 11 from Alabama, six from Mississippi, two from Louisiana, and five from Texas. The isolates were obtained from the onset of the U.S. epidemic (2005 to 2007) to the recent findings in Texas and Louisiana in 2015.

The 125 U.S. isolates included a special collection of 13 R. lauricola isolates obtained from symptomatic sapwood of recently killed redbay trees in 2015 from a small area in coastal Georgia (Halfmoon Landing, Pembroke, St. Simmon's Island, and Jekyll Island). The genetic variation of these 13 isolates was compared with the genetic variation of 16 isolates collected in the same area during the early epidemic (2005 to 2007).

For some isolates, DNA was extracted before storage, but most isolates were previously stored in $15 \%$ glycerol at $-80^{\circ} \mathrm{C}$. For DNA extraction, cultures were plated on MYEA (2\% malt extract, $0.2 \%$ Difco yeast extract, $1.5 \%$ agar) or CSMA and cultured in the dark at room temperature. Mycelium and spores were scraped from the plates and DNA was extracted using a Promega Wizard Kit (Promega, Madison, WI) with cultures 5 to 7 days old or using PrepMan Ultra with cultures 2 to 7 days old.

Large subunit ribosomal (28S) rDNA. The D1/D2 barcoding region of the 28S rDNA gene (Harrington et al. 2010) was sequenced for all studied isolates. In earlier studies (Harrington and Fraedrich 2010; Harrington et al. 2010, 2011), all U.S. isolates had the identical LSU sequence ( $L S U-A$, GenBank Accession No. EU177438), but a single base substitution was detected at position 507 of the 545-bp fragment ( $L S U-G$, HQ688667) in most Asian isolates of $R$. lauricola (Harrington et al. 2011). For identification of the base substitution, PCR was carried out using primers LROR and LR5 $(1 \mu \mathrm{M})$ with the following program conditions: $85^{\circ} \mathrm{C}$ for $2 \mathrm{~min}$; followed by
35 cycles of $95^{\circ} \mathrm{C}$ for $70 \mathrm{~s}, 58^{\circ} \mathrm{C}$ for $60 \mathrm{~s}$, and $72^{\circ} \mathrm{C}$ for $80 \mathrm{~s}$; followed by a final extension of $72^{\circ} \mathrm{C}$ for $15 \mathrm{~min}$. The PCR products were purified with the GFX PCR DNA and Gel Band Purification Kit and Sanger sequenced with primers LROR and LR3 using a 3730xl DNA Analyzer at the DNA Facility at Iowa State University, Ames.

Small subunit intron ribosomal (18S) rDNA. A 432-bp intron was found to be present in the 18S rDNA (SSU) gene of isolates of $R$. lauricola in the United States (KX958434), and primers were designed to see if all isolates of $R$. lauricola had this intron. Ophiostomatales forward primer SR9Rlaur (5'-CAATTGTCAGAGGT GAAATTCTTGG-3') is upstream from the intron, and the $3^{\prime}$ end of the reverse primer (SR10lrIn, 5'-CGCCGCCCTCACTTTTCC-3') is $25 \mathrm{bp}$ into the intron. If the 400 -bp PCR product was amplified, the intron was considered present. If no PCR product was amplified, the intron was considered absent. Primer concentration and PCR thermal cycling conditions were as described for the $28 \mathrm{~S}$ gene.

Microsatellite markers. Two microsatellite markers developed by Dreaden et al. (2014) (CHK, GenBank KF381410; and IFW, KF381411) were used to identify polymorphisms in the Asian and U.S. populations. The forward primers were fluorescently labeled (Integrated DNA Technologies, Inc., Coralville, IA) with 5' 6FAM for $C H K$ and with $5^{\prime} \mathrm{HEX}$ for $I F W$. The primer pairs $(0.5 \mu \mathrm{M})$ were used in separate PCR reactions in a 96-well thermal cycler (PTC-100 MJ Research Inc., Watertown, MA), generally with the following program conditions: $95^{\circ} \mathrm{C}$ for $5 \mathrm{~min}$; followed by 37 cycles of $95^{\circ} \mathrm{C}$ for $15 \mathrm{~s}, 58^{\circ} \mathrm{C}$ for $15 \mathrm{~s}$, and $68^{\circ} \mathrm{C}$ for $45 \mathrm{~s}$; with a final extension of $68^{\circ} \mathrm{C}$ for $5 \mathrm{~min}$. Sizes of the PCR products were determined with a four-capillary Applied Biosystems 3730 DNA Analyzer and Applied Biosystems GeneScan (Thermo Fisher Scientific Inc., Waltham, MA) at the DNA Facility at Iowa State University and Peak Scanner Analysis Software v1.0 (Thermo Fisher Scientific Inc.) using the GS500(-250) setting. To confirm differences among alleles as determined by GeneScan, at least one PCR product representative of each allele was sequenced with the same respective PCR primers but without fluorescent labeling.

Mating-type genes. Primers were developed to amplify a portion of one of the MAT1-1 genes (MAT1-1-3) and a portion of the MAT1-2 gene (MAT1-2-1) of R. lauricola. For the MAT1-1-3 gene, Ophiostomatales primers Oph-MAT1F1 (5'-ATGKCCRATGARGAYTG CT-3') and Oph-MAT1R2 (5'-GGCGKTKGCRTTGTAYTTGTA-3') designed by Duong et al. (2015) and Arie et al. (1997) thermocycling conditions with a $47^{\circ} \mathrm{C}$ annealing temperature were used with DNA from $R$. lauricola isolate $\mathrm{C} 2591$ from Taiwan. After agarose gel electrophoresis, multiple bands were seen, and the strongest band, about $490 \mathrm{bp}$ in size, was gel-band excised and purified using the GFX PCR DNA and Gel Band Purification Kit. The PCR product was directly sequenced with the same primers. The obtained 481-bp sequence was confirmed to be homologous with the MAT1-1-3 gene of other Ophiostomatales using BLASTx (Altschul et al. 1990). New primer pairs were designed from this sequence using Oligo v5 (Molecular Biology Insights, Inc., Colorado Springs, CO). Primers LepMAT1F1 (5'-GKCCGATGARGAYTGC-3') and RlrLpt13R (5'ACCAGGATACATCTGCTTGTG-3') amplified a single 465-bp product with the thermocycling conditions of Arie et al. (1997) and DNA extracted from some, but not all, Asian isolates of $R$. lauricola. The PCR product obtained from Taiwanese isolate C2644 of $R$. lauricola was directly sequenced with the same primers, and the translated BLASTx search with this DNA sequence (KX951454) matched most closely to the predicted protein sequences of Grosmannia clavigera mating-type protein 1-1-3 (88\% identity, AGH03173), Leptographium longiclavatum mating-type protein 1-1-3 (88\% identity, AGH03201), the Ophiostoma querci mating-type protein 1-1-3 (67\% identity, AFD53623) (Fig. 1). The translated sequence from isolate C2644 (KX951454) consisted of 122 amino acid residues and two introns, $52 \mathrm{bp}$ and $46 \mathrm{bp}$ in length, respectively.

In order to identify a marker for the MAT2 mating type, PCR was performed using the degenerate HMG1 and HMG2 primers and thermocycling conditions described by Arie et al. (1997), with a $55^{\circ} \mathrm{C}$ annealing temperature. A PCR product of $293 \mathrm{bp}$ was obtained with DNA extracted from each of three isolates: C3472 from the United 
States; C2589 from Taiwan; and C2661 from Japan. The products were directly sequenced with the same primers and aligned, with no differences among the three DNA sequences. The nucleotide sequence was confirmed to be homologous with the MAT1-2-1 gene of Ophiostomatales using a BLASTx search. The new internal primers HMGRlrF (5'-TATCGCAAGGACCATCACAAG-3') and HMGRlrR (5'- GTAGCGGTARTNAGGATGAAG - 3') were developed and consistently amplified a 260-bp product based on agarose gel electrophoresis, though a faint band directly above the strong $260 \mathrm{bp}$ product was produced in some amplifications. The $260 \mathrm{bp}$ product from isolate C2264 from the United States was directly sequenced with the same primers. A translated BLASTx search with this DNA sequence (KX951454) found that it matched most closely with the predicted protein sequences of $L$. terebrantis HMG mating-type protein 1-2-1 (AGH03134), G. aurea HMG mating-type protein 1-2-1 (AGH03141), and G. clavigera HMG mating-type protein 1-2-1 (EFX05114) (Fig. 2). The sequence from isolate C2264 was predicted to have 60 amino acid residues and an intron of $78 \mathrm{bp}$. The intron begins at a conserved serine position, coinciding with the intron region in $O$. querci and other Ascomycota (Wilken et al. 2012) (Fig. 2).

Two separate PCR reactions with the primers $(2 \mu \mathrm{M})$ for the respective mating-type genes were run with DNA extracted from each isolate using the following cycling conditions: $95^{\circ} \mathrm{C}$ for $5 \mathrm{~min}$; followed by 35 cycles of $95^{\circ} \mathrm{C}$ for $30 \mathrm{~s}, 58^{\circ} \mathrm{C}$ for $30 \mathrm{~s}$, and $72^{\circ} \mathrm{C}$ for $30 \mathrm{~s}$; with a final extension of $72^{\circ} \mathrm{C}$ for $5 \mathrm{~min}$. The products were examined for the correct band sizes in agarose gels (Fig. 3), and each isolate was classified as MAT1 (MAT1-1-3 product) or MAT2 (MAT1-2-1 product). The sizes of the respective PCR products did not vary among the extracted DNA samples using agarose gel electrophoresis.

Analysis of Molecular Variance (AMOVA). Only Asian populations sampled in 2009 were used for AMOVA. Partition of total variance on Euclidean distances was performed in ARLEQUIN 3.5 (Excoffier and Lischer 2010) using the alleles for LSU, CHK and IFW microsatellite loci, and the idiomorphs of the mating-type locus.
R.lauricola
SDEDCSI IYDTHSKAYRLVPASDVGS IDEQRFRIVGCAKAITTELS---ATASPSKPRIPRPPNAWI IY
G.clavigera
ADDDCCILYDAQAKTYRLVPVSDSKFVDLKRFRVMGYARA--SDDG---TTPAP-EPRIPRPPNAWIIY
L. longiclavatum
ADDDCCILYDAQAKTYRLVPVSDSKFVDLKRFRVMGYARA--SDDG---TTPAP-EPRIPRPPNAWIIY
o. himal-ulmi
SNEDCSIVYDHQSRTFRLTQMVNANTPCAGRFEI I GHAKAANKEAKNPEPVTTT-ESRIPRPPNAWI IY
o. novo-ulmi
SNEDCS IVYDHQSRTFRLTQMVNASTPCADRFEI I GHAKAANKEAKNPEPVTTT-ESRIPRPPNAWI IY
o. querci
o. montium
S. schenkii
SNEDCSIVYDHESRTFRLTQMADESTTCASRFEVVGHAKGVNKEVSNPVPTTTSSESRI PRPPNAWI IY
SNEDCSIVYDHQSRTFRLTQTADTDVPCPERFEVVGHAKAVVKDDANTTVAGAK-QSRI PRPPNAWIIY
ADEDCSIVYDSETRTFRLSQMADGEALEAPRYTLVGHAKAV-EDSGDISANATK-SHRIPRPPNAWIIY

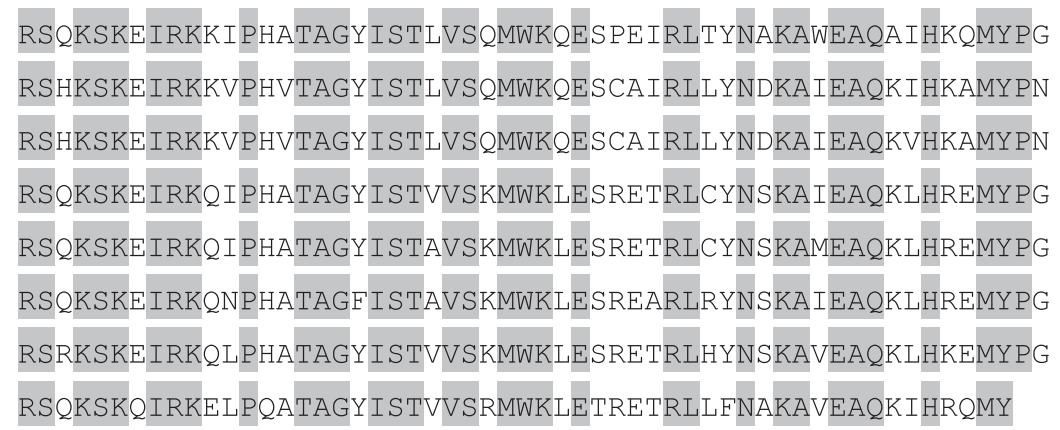

RSQKSKEIRKKIPHATAGYISTLVSQMWKQESPE IRLTYNAKAWEAQAIHKQMYPG RSHKSKEIRKKVPHVTAGYISTLVSQMWKQESCAIRLLYNDKAIEAQKIHKAMYPN

G.clavigera

L. longiclavatum

O.himal-ulmi

O. novo-ulmi

O.querci

O. montium

S.schenkii

Fig. 1. Alignment of partial amino acid sequences of the translated MAT1-1-3 genes of Raffaelea lauricola and other Ophiostomatales. Shaded amino acids are conserved across all sequences included in the alignment. The $R$. lauricola sequence was obtained from isolate C2644 from Taiwan. Accession numbers: $R$. lauricola = KX951453; Grosmannia clavigera = AGH03173; Leptographium longiclavatum = AGH03201, Ophiostoma himal-ulmi = AHL24885; O. novo-ulmi = ACZ53925; 0. querci = AFD53623; 0. montium = AGH03256; Sporothrix schenkii = AGG09667.

$\begin{array}{ll}\text { R. lauricola } & \text { YRKDHHKAVKQSNPELSNNEIS } \\ \text { L. terebrantis } & \text { YRKDHHKAVKKSDPELSNNEI } \\ \text { G. aurea } & \text { YRKDHHKAVKKSDPELSNNEI } \\ \text { G. clavigera } & \text { YRKDHHKAVKKSDPELSNNEIS } \\ & \\ \text { R. lauricola } & \text { HMMAMEIKRQVEKLHPDYRY } \\ \text { L. terebrantis HTMAIEIKRQVERLHPDYRY } \\ \text { G. aurea } & \text { HTMAIEIKRQVERLHPDYRY } \\ \text { G. Clavigera } & \text { HTMAIEIKRQVERLHPDYRY }\end{array}$

Fig. 2. Alignment of the amino acid sequences of the HMG box region of the translated MAT1-2-1 genes of Raffaelea lauricola and other Ophiostomatales. Shaded amino acids are conserved across all sequences included in the alignment. The $R$. lauricola sequence was obtained from isolate C2264 from the United States. Accession numbers: $R$. lauricola sequence $=$ KX951454; Leptographium terebrantis $=$ AGH03134; Grosmannia aurea $=$ AGH03141; G. clavigera $=$ EFX05114 . 
Variation was determined among sites, among collection dates within a site, and within a collection date at a particular site. The significance of the variance components linked with various levels of genetic structure was tested with nonparametric permutation procedures, which was set to 20,000 permutations.

Pairwise $\mathbf{F}_{\mathbf{S T}}$. Comparisons of populations at each collection site in Asia and the U.S. population were made by calculating pairwise $\mathrm{F}_{\mathrm{ST}}$ with ARLEQUIN 3.5 using the alleles for LSU, CHK and $I F W$ microsatellite loci, and the mating-type idiomorphs. All 2009 sampling dates were combined for each Asian site (population) in the analysis, except that the Hsinhsien population collected in 2014 was included as a separate population from the 2009 Hsinhsien collections. The significance of genetic difference among populations was tested with nonparametric procedures (1000 permutations).

Genotypic diversity. Every unique combination of alleles among the four genetic markers was considered a unique genotype. Relationships among all genotypes were illustrated by using a matrix of total character differences and UPGMA (unweighted pair group method with arithmetic mean) with 1000 bootstrap replicates in PAUP* v4.0 b10 (Swofford 2002).

Multilocus genotypic diversity was calculated using Stoddart and Taylor's (1988) $G$ with the "poppr" v2.0.2 R package (Kamvar et al. 2014). Following the K-allele model, all alleles were treated as equal to each other, meaning that a mutation from one allele to any other allele is equally probable (Kimura 1983). $G$ values were rarefied (Grünwald et al. 2003; Grünwald and Hoheisel 2006) according to the maximum possible number of genotypes in the smallest population size sampled $(n=5)$ using the poppr v2.0.2 R package (Kamvar et al. 2014) in $\mathrm{R}$ v3.2.2.

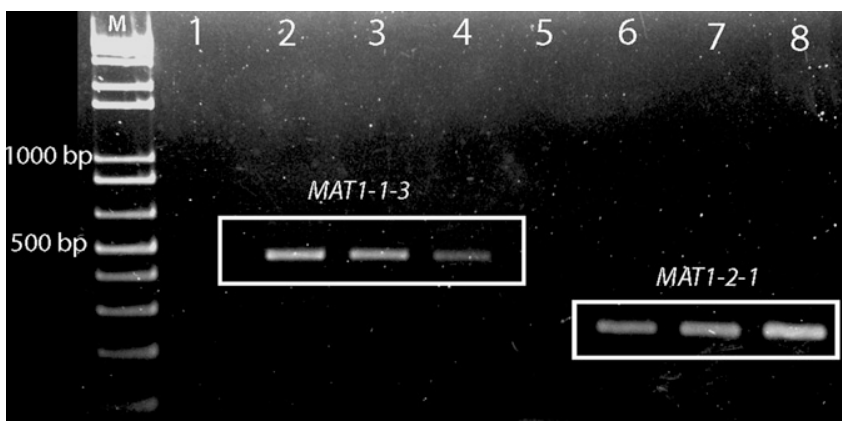

Fig. 3. Agarose gel of PCR products of the partial MAT1-1-3 (about $500 \mathrm{bp}$ ) and MAT12-1 (about $250 \mathrm{bp}$ ) genes from six $R$. lauricola isolates, three of each mating type (MAT1 and MAT2, respectively): C2644; C2659; C2636; C2646; C2667; and C2264. The first lane contains the $1 \mathrm{~Kb}$ Plus DNA Ladder (Life Technologies, Carlsbad, CA).
Nei's gene diversity $(H)$ (Nei 1987) for the Fushan and Hsinhsien, Taiwan populations, the Koshi, Japan, population, and the U.S. population was calculated with and without clone correction using the poppr v2.0.2 R package.

Linkage disequilibrium. Asian populations were analyzed with and without clone correction for linkage disequilibrium using the index of association $\left(\mathrm{I}_{\mathrm{A}}\right)$ (Agapow and Burt 2001) in the poppr v2.0.2 R package to test populations for deviation from purely sexual outcrossing. Sampling was set to 999 permutations to test the significance of the $\mathrm{I}_{\mathrm{A}}$ value.

\section{Results}

In total, 55 isolates from Taiwan (49 from populations), 10 isolates from Japan, and 125 isolates from the United States were analyzed for genetic variation using the D1/D2 region of $28 \mathrm{~S}$ rDNA, an $18 \mathrm{~S}$ rDNA intron, the $C H K$ and $I F W$ microsatellite markers, and the mating-type locus.

Large subunit ribosomal (28S rDNA). Of the 49 isolates of $R$. lauricola collected in 2009 from two sites in Taiwan, 45 had the $L S U-G$ allele and four had the $L S U-A$ allele, while the 2014 sample from Taiwan included three isolates with the $L S U-G$ allele and two isolates with the $L S U-A$ allele (Table 1). An isolate from Lienhuachih, Taiwan had the $L S U-G$ allele. Of the 10 isolates of $R$. lauricola from Japan, eight had the $L S U-G$ allele and two had the $L S U-A$ allele (Table 1). Each of the 125 sampled isolates from the United States had the $L S U-A$ allele.

Small subunit intron ribosomal (18S rDNA). Although the presence or absence of the intron in the 18S rDNA region was expected to be a source of genetic variation, each of the 125 isolates from the United States, each of the 55 Taiwanese isolates, and each of the 10 Japanese isolates amplified a 400-bp product with the intronspecific primers.

Microsatellite markers. Fourteen different PCR product sizes ranging from 326 to $401 \mathrm{bp}$ and varying by $3 \mathrm{bp}$ increments were detected among the Asian isolates using the $C H K$ primers (Table 1). A representative PCR product for each band size was directly sequenced with the PCR primers, and every unique allele had the same number of bp as read by GeneScan, except the $373 \mathrm{bp}$ read by GeneScan was actually $374 \mathrm{bp}$ and the 400 bp read by GeneScan was actually $401 \mathrm{bp}$. All sequences for $C H K$ products had the expected number trinucleotide repeats of TCT. Some infrequent base substitutions occurred in some of the alleles, both inside and outside of the trinucleotide repeat region. The most common allele size in Asia for CHK was $329 \mathrm{bp}$, which was the only allele size found for the CHK locus in the U.S. isolates (Table 1). Three $C H K$ alleles, including $C H K-329$, were found in both Taiwan and Japan. Four of the $\mathrm{CHK}$ alleles were found only in Japan, and seven of the $\mathrm{CHK}$ alleles were found only in Taiwan.

Five different PCR product sizes, which varied by 3-bp increments, were found with the $I F W$ microsatellite marker: $306 ; 312$;

Table 1. Alleles for the $28 \mathrm{~S}$ rDNA (LSU), CHK and IFW microsatellite markers, and mating type genes found among Raffaelea lauricola isolates from two sites in Taiwan, one site in Japan, and across the United States

\begin{tabular}{|c|c|c|c|c|c|c|c|}
\hline Country & Location & Year & $\begin{array}{l}\text { No. of } \\
\text { isolates }\end{array}$ & $\begin{array}{l}\text { Isolates with } G \\
\text { or A alleles for } \\
28 S \text { rDNA }^{\mathrm{a}}\end{array}$ & $\mathrm{CHK}$ alleles ${ }^{\mathrm{b}, \mathrm{c}}$ & $I F W$ alleles $^{\mathbf{b}, \mathbf{c}}$ & $\begin{array}{c}\text { Isolates } \\
\text { MAT1/MAT2 }^{d}\end{array}$ \\
\hline \multirow[t]{3}{*}{ Taiwan } & Hsinhsien & 2009 & 26 & $\mathrm{G}(24) / \mathrm{A}(2)$ & $329(14), 344(1), 350(4), 365(6), 374$ (1) & $318(1), 321(25)$ & $23 / 3^{* * \mathrm{e}}$ \\
\hline & & 2014 & 5 & $\mathrm{G}(3) / \mathrm{A}(2)$ & $329(3), 350(1), 401(1)$ & $318(2), 321(3)$ & $2 / 3$ \\
\hline & Fushan & 2009 & 23 & $\mathrm{G}(21) / \mathrm{A}(2)$ & $\begin{array}{l}\text { NULL (2), } 329 \text { (10), } 344 \text { (2), } 347 \text { (3), } 350 \\
\text { (4), } 356 \text { (1), } 368 \text { (1) }\end{array}$ & $318(6), 321(17)$ & $14 / 9$ \\
\hline Japan & Koshi & 2009 & 10 & G (8)/A (2) & $\begin{array}{l}326(2), 329(2), 341(1), 350(1), 353(1), \\
365(1), 371(2)\end{array}$ & $306(1), 318(5), 321(4)$ & $7 / 3$ \\
\hline USA & All USA & $2005-2015$ & 125 & $\mathrm{G}(0) / \mathrm{A}(125)$ & $329(125)$ & $312(1), 318(109), 327(15)$ & $0 / 125^{* *}$ \\
\hline
\end{tabular}

a The two 28S rDNA alleles are the dominant Asian (G) allele and the U.S. (A) allele.

${ }^{\mathrm{b}}$ Allele sizes in bp based on GeneScan readings.

${ }^{\mathrm{c}}$ Number of isolates with that allele in parentheses.

${ }^{\mathrm{d}}$ Isolates yielding a MAT1-1-3 gene PCR product were treated as MAT1, and isolates yielding a MAT1-2-1 gene PCR product were considered as MAT2

e $* *$ Significantly different from the expected $1: 1$ ratio $(P \leq 0.001)$. 
318, 321; and 327 bp (Table 1). A representative PCR product was sequenced for each of the five alleles, which revealed a bias in GeneScan results for all the $I F W$ alleles by negative $4 \mathrm{bp}$, that is, based on direct sequencing, the alleles listed above were $310,316,322,325$, and $331 \mathrm{bp}$, respectively. The five microsatellite alleles had varying numbers of trinucleotide repeats of GAC, and there was a small number of base substitutions in some of the alleles, both inside and outside of the repeat region. Only three alleles were found for the $I F W$ locus in Asia; the most common were $318 \mathrm{bp}$ and $321 \mathrm{bp}$, and one isolate in Japan had an allele size of $306 \mathrm{bp}$ (Table 1). The IFW306 allele had one AGC repeat near the $5^{\prime}$ end of the PCR product, in addition to the GAC repeats.

The most common $I F W$ allele size in the United States was $318 \mathrm{bp}$, which was also found in Asia. Fifteen isolates from coastal Georgia had the IFW-327 allele (Fig. 4, 5), and one isolate from Demopolis in Marengo County, Alabama had the $I F W-312$ allele (Fig. 4, Table 1).

Mating-type genes. All but one of the 190 isolates of $R$. lauricola yielded either a portion of the MAT1-1-3 gene or a portion of the MAT1-2-1 gene in PCR analysis (Fig. 3). Only the MAT1-2-1 mating-type gene product was found among isolates from the United States. Both mating-type genes were found among isolates from Taiwan and Japan (Table 1). Isolate C2688 from Taiwan had positive amplifications for both mating-type markers; it tested positive for the MAT1-1-3 gene five out of five times, tested as positive for the MAT1-2-1 gene two out of four times, and had ambiguous results for the MAT1-2-1 gene two out of four times. Isolate C2688 was perhaps a mixed culture, but it had only single PCR products for the two microsatellite markers. It was categorized as the MAT1 mating type in analyses because the MAT1-1-3 PCR product was amplified more consistently than the MAT1-2-1 product.

The ratio of isolates found to have the MAT1-1-3 product, treated as the MAT1 mating type, to isolates found to have the MAT1-2-1 product, treated as the MAT2 mating type, was analyzed for deviation from a 1:1 ratio with a Chi-Squared Goodness of Fit test (R statistical package v3.2.2, R Core Team, Vienna). The $\chi^{2}$ values did not indicate a significant deviation from the expected 1:1 ratio in the 2009 Fushan, 2009 Koshi, and 2014 Hsinhsien populations, but there was a significant deviation from 1:1 in the 2009 Hsinhsien population $(P \leq 0.001)$ (Table 1$)$, which was dominated by the GCD1 ( $L S U-G, C H K-329, I F W-321$, MAT1) genotype. When this genotype was excluded from the analysis, the 2009 Hsinhsien population still showed a significant deviation from 1:1 $(P \leq 0.05)$.

Population structure in Asia. In AMOVA analysis with all four genetic markers, the only significant variation $(P \leq 0.05)$ among isolates from the 2009 Asian populations was found within populations (90\%) (Table 2). A small percentage of variation was found among the three individual sites and among the two sampling dates within sites, but these sources of variation were not significant.

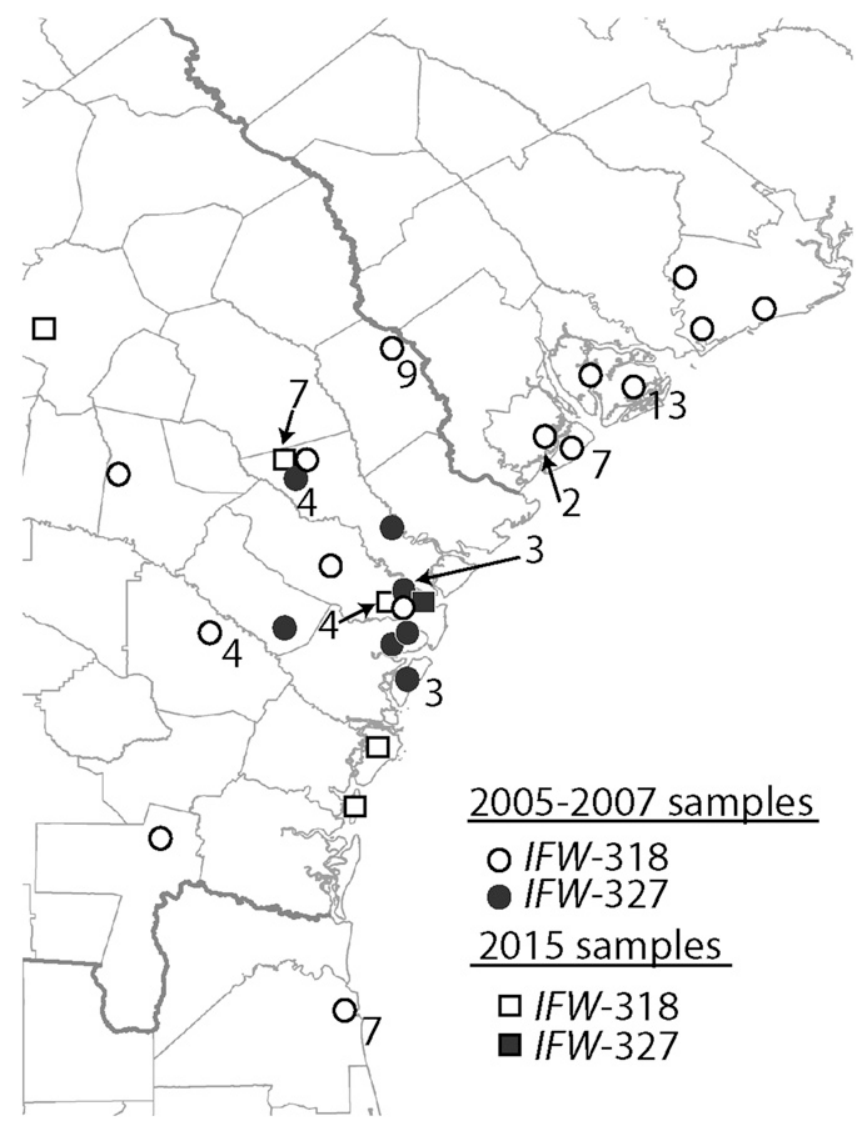

Fig. 5. Distribution of IFW microsatellite alleles for Raffaelea lauricola isolates collected in South Carolina, Georgia, and northern Florida during the early epidemic (2005 to 2007) and after the epidemic (2015). The two IFW alleles found in this region are IFW-318 (white fill) and IFW-327 (black fill). A circle indicates an isolate was collected between 2005 and 2007, and a square indicates an isolate was collected in 2015. Each symbol represents one isolate, unless indicated otherwise by a number to the right of the symbol or indicated by an arrow.

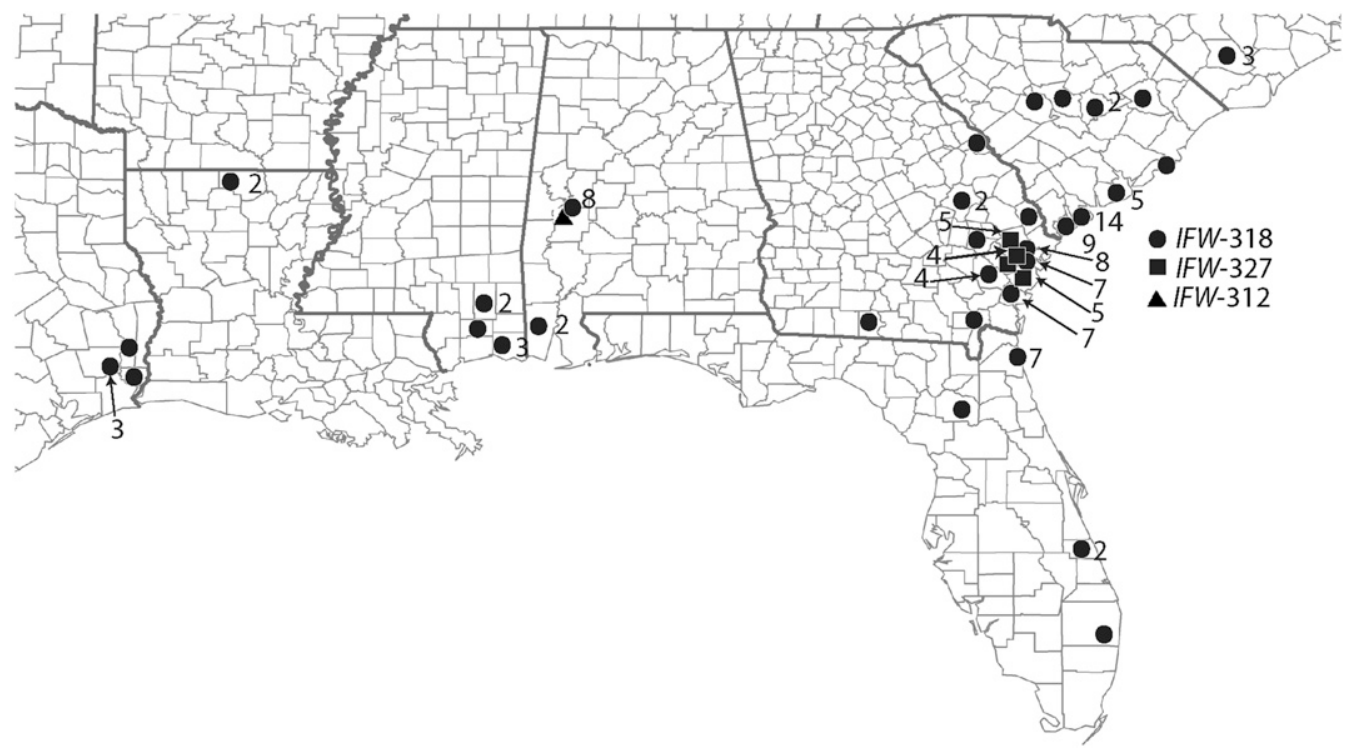

Fig. 4. Distribution of microsatellite IFW alleles for Raffaelea lauricola isolates collected in the United States. The three IFW alleles are IFW-318 (circle), IFW-327 (square), and IFW-312 (triangle). Each symbol represents one isolate, unless indicated otherwise by a number to the right of the symbol or indicated by an arrow. 
Because variation among sampling dates was insignificant, data from different sampling dates in 2009 were combined for each respective collection site in other population analyses.

Genetic variation between populations was analyzed with all four genetic markers using the pairwise $\mathrm{F}_{\mathrm{ST}}$ test. The 2009 Asian populations were all significantly different from each other, except when comparing the Koshi, Japan, population to the Fushan, Taiwan, population (Table 3). In addition, the 2009 and 2014 Hsinhsien populations were significantly different from each other.

Genetic diversity in Asian populations. The four combined marker types resolved 21 genotypes from Asia among the 65 tested isolates. The genotypes were scattered throughout the UPGMA tree based on Nei's genetic distance matrices, with no notable geographic clustering (Fig. 5). Genotype GCD1 was common in each Asian population.

Ten genotypes were found in Fushan among the 19 isolates analyzed, and seven genotypes were found in Japan among the 10 isolates analyzed (Table 4). The genotypic diversity values $(G)$ were relatively high (maximum possible value of 5.0) for each of the Asian populations (Table 4). The $2014 \mathrm{Hsinhsien}$ population (from a single tree) had the highest value (5.0), and the 2009 Hsinhsien population had the lowest value (2.75) among Asian populations. Nei's gene diversity values $(H)$ also were relatively high for the Asian populations (Table 4). The 2014 Hsinhsien population had the highest $H$ value (=0.625). The $H$ value increased greatly for the 2009 Hsinhsien population after clone correction.

Linkage disequilibrium. The linkage disequilibrium analysis for the four genetic markers was performed using index of association $\left(\mathrm{I}_{\mathrm{A}}\right)$ values to test for random mating in the Taiwan, Japan, and Asia populations overall. The value of $\mathrm{I}_{\mathrm{A}}$ should be near zero in a randomly mating population with only sexual reproduction. $\mathrm{I}_{\mathrm{A}}$ values were significantly greater than zero without clone correction for Taiwan, Japan, and the Asia population overall $(P \leq 0.01)$ (Table 5). Deviation from purely random mating could be explained by dominance of one or a few genotypes within a population due to clonal reproduction. The $\mathrm{I}_{\mathrm{A}}$ values were not significantly different from zero with clone correction (only one isolate of each genotype was retained) for Taiwan, Japan, and Asia populations overall (Table 5).

Genotypic diversity in the U.S. population. The 125 U.S. isolates differed at only the $I F W$ locus, for which there were only three $I F W$ alleles. The U.S. population had a lower $G$ value (1.32) and a lower $H$ value than the Asian populations, with or without clone correction $(H=0.250$ and 0.0591 , respectively) (Table 4$)$. The most common U.S. genotype was found at both collection sites in Taiwan, but it was not common (Fig. 6). The three U.S. genotypes shared the $L S U$-A variant and MAT1-2-1 gene with a genotype in Japan, but the Japanese genotype differed at the microsatellite loci (Fig. 6). The pairwise $F_{S T}$ test results using all four markers suggest that the U.S. population was significantly different from all Asian populations $(P \leq 0.01)$ (Table 3$)$.

During the early phase of the laurel wilt epidemic (2005-2007), 14 isolates with the rare $I F W-327$ allele were collected in southeastern Georgia (Bryan, Liberty, McIntosh, and Long Counties) (Fig. 5).
In a resampling from 13 wilted redbay trees in Bryan, Liberty, and nearby Glynn counties in 2015, only one isolate (from near Halfmoon Landing, Liberty County) had the $I F W-327$ allele, and the other 12 isolates had the IFW allele $(I F W-318)$ that was dominant throughout the United States (Fig. 5). A $\chi^{2}$ test revealed that there was a significant difference $\left(\chi^{2}=143.57, P \leq 0.001\right)$ between the ratio of isolates with the $I F W-327$ allele in 2005-2007 (14 with $I F W-327$ allele versus 2 with $I F W-318$ allele) and the ratio of isolates with the same allele in the same region in 2015.

\section{Discussion}

The presence of only one mating type in the U.S. population of $R$. lauricola and the near uniformity of microsatellite markers and LSU rDNA sequences strongly suggest that the pathogen population in the United States has gone through a severe genetic bottleneck. This supports the hypothesis that there was a single introduction of $R$. lauricola to the United States. Both mating types of $R$. lauricola were found within the native range of $X$. glabratus in Taiwan and Japan, and there was a much higher level of genetic diversity in the Asian populations than would be expected for a purely asexual species. This is the first indication that a symbiont of an ambrosia beetle has two mating types and may be capable of sexual reproduction.

Substantial genetic diversity was found in Asia, where the $\mathrm{CHK}$ locus alone had 14 alleles. Pairwise $\mathrm{F}_{\mathrm{ST}}$ tests indicated some differences among Asian populations, but the AMOVA analysis found that the only significant source of genetic variation was from within populations. Genotypic diversity $(G)$ was high, with the 2014 Hsinhsien, Taiwan, population (from a single tree) having the highest $G$ value. Nei's $H$ values were generally high for Asian populations, with or without clone correction, suggesting greater genetic diversity than would be expected for purely clonal populations.

There are few studies on the genetic diversity of other ambrosia beetle symbionts. Restriction site-associated DNA sequencing was used to analyze genetic diversity and population structure among populations of $R$. quercus-mongolicae, a mycangial symbiont of Platypus koryoensis associated with oak mortality in South Korea (Kim et al. 2016). Low genetic diversity suggested that the fungus was introduced to South Korea. Alternatively, R. quercus-mongolicae may be asexual. In contrast, Takahashi et al. (2015) reported high genetic diversity in $R$. quercivora, a mycangial symbiont of $P$. quercivorus that is associated with oak mortality in Japan. Three to six genotypes of $R$. quercivora were identified in the mycangia of a single adult, and five to 10 genotypes of $R$. quercivora were detected in individual galleries. Such high genotypic diversity could be associated with an active sexual state. However, Takahashi et al. (2015) used di-nucleotide repeats as markers, and such markers can show a lack of reproducibility compared with trinucleotide markers (Simpson et al. 2013; Steimel et al. 2004).

Most fungal symbionts of ambrosia beetles bud asexually in mycangia, and, until recently it had been thought that all ambrosia fungi only reproduce asexually. However, two Raffaelea spp. may form perithecia. Musvuugwa et al. (2015) reported perithecia and ascospores of $R$. vaginata in beetle galleries of a Lanurgus sp.
Table 2. Analysis of molecular variance (AMOVA) using four genetic markers of Raffaelea lauricola populations isolated from Xyleborus glabratus adults trapped at three sites in Asia and up to four sampling dates in 2009

\begin{tabular}{lcccc}
\hline & d.f. & $\begin{array}{c}\text { Variance } \\
\text { components }\end{array}$ & $\begin{array}{c}\text { Proportion of variance } \\
\text { components (\%) }\end{array}$ & $\boldsymbol{P a}^{\mathbf{a}}$ \\
\hline Among sites $^{\mathrm{b}}$ & 2 & 0.04004 & 4.69 & 0.065 \\
$\begin{array}{l}\text { Among sampling } \\
\text { dates within sites }\end{array}$ & 3 & 0.04912 & 5.76 & 0.203 \\
$\begin{array}{l}\text { Within populations } \\
\text { Total }\end{array}$ & 47 & 0.76404 & 89.55 & 0.008 \\
\hline
\end{tabular}

a The $P$ value is for the null hypothesis that there is no significant variation at that level based on 20,022 permutations.

$\mathrm{b}$ The populations were from three sites: Hsinhsien, Taiwan; Fushan, Taiwan; and Koshi, Japan.
Table 3. Pairwise $\mathrm{F}_{\mathrm{ST}}$ values using four genetic markers between Raffaelea lauricola populations from Japan, Taiwan, and the United States

\begin{tabular}{llccc}
\hline & $\begin{array}{c}\text { Japan } \\
\mathbf{2 0 0 9}\end{array}$ & $\begin{array}{c}\text { Fushan } \\
\mathbf{2 0 0 9}\end{array}$ & $\begin{array}{c}\text { Hsinhsien } \\
\mathbf{2 0 0 9}\end{array}$ & $\begin{array}{c}\text { Hsinhsien } \\
\mathbf{2 0 1 4}\end{array}$ \\
\hline $\begin{array}{l}\text { Japan 2009 } \\
\text { Fushan 2009 }\end{array}$ & 0.01112 & & & \\
$\begin{array}{l}\text { Hsinhsien } \\
2009\end{array}$ & $0.16413^{* * a}$ & $0.06466^{* \mathrm{~b}}$ & & \\
$\begin{array}{c}\text { Hsinhsien } \\
2014\end{array}$ & -0.0514 & 0.00439 & $0.21246^{*}$ & \\
USA & $0.80322^{* *}$ & $0.81058^{* *}$ & $0.86767^{* *}$ & $0.74146^{* *}$ \\
\hline
\end{tabular}

a ** Significant difference between populations $(P \leq 0.01)$.

$\mathrm{b} *$ Significant difference between populations $(P \leq 0.05)$. 
(Coleoptera: Curculionidae: Scolytinae: Micracini) in Olea capensis in South Africa, but Lanurgus spp. are not known to be ambrosia beetles. Davidson (1966) reported perithecia in cultures of $R$. seticollis from galleries of an unidentified ambrosia beetle in hemlock (Tsuga canadensis) in New York.

The MAT1 and MAT2 mating types were detected in roughly equal proportions among the $R$. lauricola isolates from Taiwan and Japan. If $R$. lauricola only reproduces asexually in the mycangia as a budding yeast phase and in the galleries as conidia from conidiophores (Fraedrich et al. 2008; Harrington and Fraedrich 2010), then a preponderance of one of the mating types and a high level of linkage disequilibria might be expected in some populations. However, when corrected for clonal reproduction within a site, the index of association values for the Asia populations did not differ significantly from that expected for randomly mating populations. Although no perithecia have been observed in our numerous attempted crosses of $R$. lauricola isolates of opposite mating type, the 1:1 proportion of mating-type genes and the lack of linkage disequilibrium suggest that there is cryptic sexual reproduction in Asia.

The discovery of MAT1-1 and MAT1-2 idiomorphs among isolates of a fungal species has suggested cryptic sex in other supposedly asexual fungi (Kück and Pöggeler 2009). Although no mating-type genes have been identified earlier in Raffaelea spp., mating-type genes have been identified in related genera of Ophiostomatales. The MAT locus and flanking genes have been identified in Grosmannia spp. and Leptographium spp. (Duong et al. 2012, 2015; Tsui et al. 2013), in Ophiostoma ulmi, O. novo-ulmi, O himal-ulmi, O. montium, and $O$. querci (Jacobi et al. 2010; Paoletti et al. 2005, 2006; Tsui et al. 2013; Wilken et al. 2012), and in Sporothrix schenkii and $S$. brasiliensis (Teixeira et al. 2015). The MAT locus has also been partially characterized in $S$. globosa (Kano et al. 2015). Characterization of the MAT locus and development of markers for matingtype genes have demonstrated that many species of Leptographium that were thought to be asexual actually have isolates of both mating types and have the potential to sexually reproduce (Duong et al. 2013, 2016). The majority of these Leptographium spp. appear to be heterothallic rather than homothallic based on the presence of mating-type genes (Duong et al. 2016).

There are several possible opportunities in the life cycle of $X$. glabratus that could facilitate heterothallic mating of $R$. lauricola in Asia. One hypothesis is that when a mature female $X$. glabratus makes an aborted attack in a healthy tree (Fraedrich et al. 2008, 2015b), the beetle inoculates the xylem with one mating type of the fungus that then systemically colonizes the vascular system. After the tree wilts, brood attacks by $X$. glabratus are initiated, and the later attacking females may carry a $R$. lauricola strain of opposite mating type. A second possibility is that flightless males of $X$. glabratus may disperse strains of $R$. lauricola to other galleries on the same stem or branch (Kirkendall et al. 1997; Maner et al. 2013). A third opportunity is that one mature female $X$. glabratus could carry both mating types of $R$. lauricola in its mycangia, gut or exoskeleton. Based on our isolates from Japan and Taiwan, a single X. glabratus female generally carries one genotype, and therefore one mating type of $R$. lauricola in its mycangia. However, one isolate, C2688 from Taiwan, had both mating-type genes present based on PCR, suggesting that it was a mixed culture of two individual clones of opposite mating type.

In contrast to the genetic diversity of $R$. lauricola populations in Asia, the southeastern U.S. population is nearly uniform and appears to have resulted from an introduction of one or two genotypes (Fraedrich et al. 2008). Shortly after X. glabratus was first detected at Port Wentworth, near Savannah, in 2002 (Rabaglia et al. 2006), laurel wilt was noticed $20 \mathrm{~km}$ east on Hilton Head, SC, in 2004, and $25 \mathrm{~km}$ to the west (Pembroke) and $28 \mathrm{~km}$ to the south (Halfmoon Landing) in Georgia in 2005 (Fraedrich et al. 2008). Two alleles for the $I F W$ locus were detected among isolates collected in the Pembroke to Halfmoon Landing area during the early epidemic (2005 to 2007), suggesting that two closely related genotypes of $R$. lauricola were introduced simultaneously. The $I F W-327$ allele was detected only in this small area west and south of Savannah, where it dominated in the early epidemic. However, a resampling of $R$. lauricola isolates from redbay trees in the same area in 2015 found only one of 13 isolates had the $I F W-327$ allele. Perhaps the genotype with the $I F W-327$ allele was less fit and had been replaced by the genotype with the $I F W-318$ allele, the only genotype that has spread in the United States. The third allele in the United States, $I F W-312$, was found in a single isolate from a newly discovered outbreak area in Marengo Co., AL, in 2011. It is possible that the $I F W-312$ genotype was introduced from Asia with the other two genotypes. However, its presence in only one of nine isolates in Alabama and its absence from the earlier collections near Savannah suggest that the $I F W-312$ allele arose from one random mutation or two stepwise mutations that resulted in the loss of two trinucleotide repeats (Oliveira et al. 2006).

As the epidemic continues to spread, $R$. lauricola has shown the potential to kill most, if not all, American species of Lauraceae (Fraedrich et al. 2008, 2011, 2015b; Hughes et al. 2011, 2012, 2013, 2014; Mayfield et al. 2008; Ploetz and Konkol 2013). Redbay and swampbay have been the primary hosts, although sassafras appears to be a major host for the northward expansion of the epidemic outside the

Table 4. Genetic diversity of Raffaelea lauricola populations from Japan, Taiwan, and the United States using four genetic markers

\begin{tabular}{|c|c|c|c|c|c|c|c|}
\hline \multirow[b]{2}{*}{ Location } & \multirow[b]{2}{*}{ Population } & \multirow[b]{2}{*}{ Year } & \multirow[b]{2}{*}{ No. Isolates } & \multicolumn{3}{|c|}{ Nei's Gene Diversity $(H)$} & \multirow{2}{*}{$\begin{array}{c}\text { Genotypic Diversity } \\
\text { Genotypic } \\
\text { diversity }(G)^{\mathbf{a}}\end{array}$} \\
\hline & & & & $\begin{array}{c}\text { No clone } \\
\text { correction }\end{array}$ & $\begin{array}{l}\text { With clone } \\
\text { correction }\end{array}$ & $\begin{array}{c}\text { No. of Genotypes/No. } \\
\text { of Isolates }\end{array}$ & \\
\hline \multirow[t]{2}{*}{ Hsinhsien, Taiwan } & HSIN & 2009 & 25 & 0.274 & 0.518 & $8 / 25$ & 2.75 \\
\hline & & 2014 & 5 & 0.625 & 0.625 & $5 / 5$ & 5.00 \\
\hline Fushan, Taiwan & FUS & 2009 & 19 & 0.450 & 0.550 & $10 / 19$ & 3.62 \\
\hline Koshi, Japan & JAP & 2009 & 10 & 0.600 & 0.607 & $7 / 10$ & 4.11 \\
\hline All USA Locations & USA & $2005-2015$ & 112 & 0.059 & 0.250 & $3 / 112$ & 1.32 \\
\hline
\end{tabular}

${ }^{a}$ Genotypic diversity with rarefaction using Stoddart and Taylor's (1988) $G$. Values of $G$ with rarefaction ranged from 1.0 (one genotype in a population) to 5.0 (each isolate in the population having a different genotype).

Table 5. Index of association $\left(\mathrm{I}_{\mathrm{A}}\right)$ values, without and with clone correction, using genetic markers for $28 \mathrm{~S}$ rDNA (LSU), $C H K$ and $I F W$ microsatellite loci, and mating type genes for isolates of Raffaelea lauricola from Taiwan and Japan

\begin{tabular}{|c|c|c|c|c|c|c|}
\hline \multirow[b]{2}{*}{ Country } & \multirow[b]{2}{*}{ No. isolates } & \multirow[b]{2}{*}{ No. genotypes } & \multicolumn{2}{|c|}{$\mathbf{I}_{\mathbf{A}}$ (No clone correction) } & \multicolumn{2}{|c|}{$\mathbf{I}_{\mathbf{A}}$ with clone correction } \\
\hline & & & No clone correction & $\overline{\text { Probability }^{\mathbf{a}}}$ & With clone correction & $\overline{\text { Probability }}$ \\
\hline Taiwan & 55 & 15 & 0.387 & 0.002 & -0.0216 & 0.573 \\
\hline Japan & 10 & 7 & 0.400 & 0.009 & 0.2234 & 0.408 \\
\hline Total Asia & 65 & 21 & 0.259 & 0.003 & -0.131 & 0.954 \\
\hline
\end{tabular}

a Probability that the index of association value does not differ from a purely sexually outcrossing population. 
natural range of redbay (Bates et al. 2015; Fraedrich et al. 2015a; Olatinwo et al. 2016;). Sassafras is highly susceptible to laurel wilt (Fraedrich et al. 2008; Riggins et al. 2011) and is a suitable host for X. glabratus (Cameron et al. 2015), but it may be a less attractive host than redbay (Hanula et al. 2008; Mayfield and Hanula 2012). Fraedrich et al. (2015b) suggested that because $X$. glabratus favors some laurel tree hosts over others for brood production, less than ideal brood hosts could limit further spread of laurel wilt. Other ambrosia beetles rarely carry spores of $R$. lauricola and may introduce them to healthy host trees (Carrillo et al. 2014; Harrington and Fraedrich 2010). However, $X$. glabratus is clearly the primary vector (Carrillo et al. 2014; Harrington et al. 2008, 2011; Harrington and Fraedrich 2010) and appears to have been responsible for spreading the pathogen throughout the Southeast.

UPGMA

GCD1
SIN1(6) FUS1(4)
SIN2(6) FUS2(2)
SIN3(1) FUS3(1)
JAP2(1) JAP1(1)

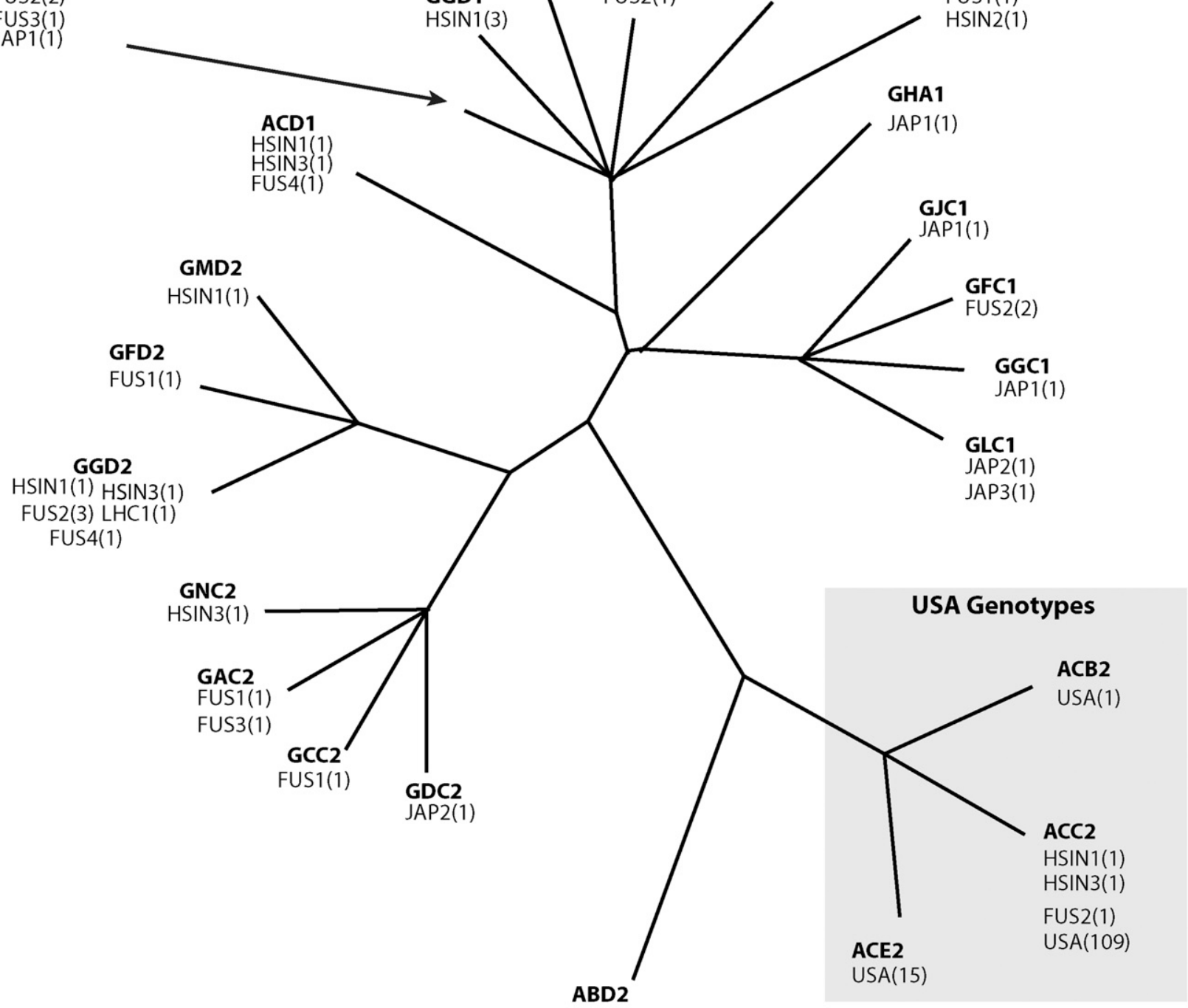

JAP2(2)

\section{1 changes}

Fig. 6. An unweighted pair group method with arithmetic mean (UPGMA) dendrogram using and the standard distance of total character difference of genotypes (bold) of Raffaelea lauricola found in Taiwan, Japan, and the United States based on the alleles of $28 \mathrm{~S}$ rDNA (LSU), CHK and IFW microsatellite markers, and the mating type locus, respectively. Allele designations are for LSU (A or G), CHK (A-N), IFW (A-E), and mating type gene idiomorphs (1 or 2). Locations are HSIN = Hsinhsien Nursery, Taiwan; FUS = Fushan, Taiwan; LHC $=$ Lienhuachih, Taiwan; and JAP = Koshi, Japan. A number to the right of the location indicates isolates collected on the same date. The number of isolates at a location/collection date with the same genotype is in parentheses. All genotypes found in the United States are enclosed in the gray box. Scale bar indicates genetic distance. 
Epidemic populations of introduced pathogens are often dominated by a highly fit genotype (Maynard-Smith et al. 1993), and the laurel wilt epidemic appears to be associated with a single genotype of $R$. lauricola. A similar spread of a single genotype (and one mating type) has been seen in epidemics caused by $O$. novo-ulmi, the cause of Dutch elm disease (DED) (Brasier 2001), a vascular wilt disease similar to laurel wilt. Later in DED epidemics, sexual reproduction apparently occurs through mating with strains of the related O. ulmi that carry the opposite mating type (Paoletti et al. 2006). Such hybridizations between species allow for generation of recombinants with new vegetative compatibility groups that reduce the spread of mycoviruses (Brasier 2001; Paoletti et al. 2006), and hybridizations may also create more aggressive strains. Del Sorbo et al. (2000) demonstrated the potential for the oak saprophyte, O. querci, to become a pathogen by artificially inserting the cerato-ulmin gene from O. novo-ulmi. The transformed strain caused a vascular wilt disease in elm under laboratory conditions.

This study demonstrates that the R. lauricola populations in Asia are highly diverse and that the U.S. population has gone through a severe genetic bottleneck. Both mating types were found in Taiwan and Japan, and high genetic diversity within populations supports the hypothesis that $R$. lauricola is capable of sexual reproduction in Asia. The laurel wilt epidemic in the United States is expanding rapidly in spite of near genetic uniformity, but sexual recombination through a hybridization event or with another introduced strain could lead to an even more aggressive or otherwise fit pathogen. Continued analyses of new $R$. lauricola populations and monitoring ports for X. glabratus are both warranted.

\section{Acknowledgments}

The authors thank Hideaki Goto, who provided dead X. glabratus from Japan for fungal isolations. We thank Cindy Wilkinson, Chase Mayers, Doug McNew, and Yeganeh Gharabigloozare for technical assistance. Graduate research funding for Caroline Wuest was provided in part by a Plant Science Fellowship from Iowa State University, grants from the USDA Forest Service, and an EAPSI Award from NSF. We also thank Robin McNeely for providing us with the U.S. map templates.

\section{Literature Cited}

Agapow, P.-M., and Burt, A. 2001. Indices of multilocus linkage disequilibrium. Mol. Ecol. Notes 1:101-102.

Altschul, S. F., Gish, W., Miller, W., Myers, E. W., and Lipman, D. J. 1990. Basic local alignment search tool. J. Mol. Biol. 215:403-410.

Arie, T., Christiansen, S. K., Yoder, O. C., and Turgeon, B. G. 1997. Efficient cloning of ascomycete mating type genes by PCR amplification of the conserved MAT HMG Box. Fungal Genet. Biol. 21:118-130.

Bates, C. A., Fraedrich, S. W., Harrington, T. C., Cameron, R. S., Menard, R. D., and Best, G. S. 2015. First report of laurel wilt, caused by Raffaelea lauricola, on sassafras (Sassafras albidum) in Alabama. J. Torrey Bot. Soc. 142:292-301.

Brasier, C. M. 2001. Rapid evolution of introduced plant pathogens via interspecific hybridization. Bioscience 51:123-133.

Cameron, R. S., Hanula, J., Fraedrich, S., and Bates, C. 2015. Progression and impact of laurel wilt disease within redbay and sassafras populations in southeast Georgia. Southeast. Nat. 14:650-674.

Campbell, A. S., Ploetz, R. C., Dreaden, T. J., Kendra, P. E., and Montgomery, W. S. 2016. Geographic variation in mycangial communities of Xyleborus glabratus. Mycologia 108:657-667.

Carrillo, D., Duncan, R. E., Ploetz, J. N., Campbell, A. F., Ploetz, R. C., and Peña, J. E. 2014. Lateral transfer of a phytopathogenic symbiont among native and exotic ambrosia beetles. Plant Pathol. 63:54-62.

Davidson, R. W. 1966. New species of Ceratocystis from conifers. Mycopathol. Mycol. Appl. 28:273-286.

Del Sorbo, G., Scala, F., Parella, G., Lorito, M., Comparini, C., Ruocco, M., and Scala, A. 2000. Functional expression of the gene cu, encoding the phytotoxic hydrophobin cerato-ulmin, enables Ophiostoma quercus, a nonpathogen on elm, to cause symptoms of Dutch elm disease. Mol. Plant-Microbe Interact. 13:43-53.

Dreaden, T. J., Davis, J. M., Harmon, C. L., Ploetz, R. C., Palmateer, A. J., Soltis, P. S., and Smith, J. A. 2014. Development of multilocus PCR assays for Raffaelea lauricola, causal agent of laurel wilt disease. Plant Dis. 98:379-383.

Duong, T. A., de Beer, Z. W., Wingfield, B. D., Eckhardt, L. G., and Wingfield,

M. J. 2015. Microsatellite and mating type markers reveal unexpected patterns of genetic diversity in the pine root-infecting fungus Grosmannia alacris. Plant Pathol. 64:235-242.

Duong, T. A., de Beer, Z. W., Wingfield, B. D., and Wingfield, M. J. 2012. Phylogeny and taxonomy of species in the Grosmannia serpens complex. Mycologia 104:715-732.
Duong, T. A., de Beer, Z. W., Wingfield, B. D., and Wingfield, M. J. 2013 Characterization of the mating type genes in Leptographium procerum and Leptographium profanum. Fungal Biol. 117:411-421.

Duong, T. A., de Beer, Z. W., Wingfield, B. D., and Wingfield, M. J. 2016. Mating type markers reveal high levels of heterothallism in Leptographium sensu lato. Fungal Biol. 120:538-546.

Excoffier, L., and Lischer, H. E. L. 2010. Arlequin suite ver 3.5: A new series of programs to perform population genetics analyses under Linux and Windows. Mol. Ecol. Resour. 10:564-567.

Fraedrich, S. W., Harrington, T. C., Bates, C. A., Johnson, J., Reid, L. S., Best, G. S., Leininger, T. D., and Hawkins, T. S. 2011. Susceptibility to laurel wilt and disease incidence in two rare plant species, pondberry and pondspice. Plant Dis. 95:1056-1062.

Fraedrich, S. W., Harrington, T. C., and Best, G. S. 2015b. Xyleborus glabratus attacks and systemic colonization by Raffaelea lauricola associated with dieback of Cinnamomum camphora in the southeastern United States. For. Path. 45:60-70.

Fraedrich, S. W., Harrington, T. C., McDaniels, B. A., and Best, G. S. 2016. First report of laurel wilt, caused by Raffaelea lauricola, on spicebush (Lindera benzoin (L.) Blume) in South Carolina. Plant Dis. 100:2330.

Fraedrich, S. W., Harrington, T. C., Rabaglia, R. J., Ulyshen, M. D., Mayfield, A. E., III, Hanula, J. L., Eickwort, J. M., and Miller, D. R. 2008. A fungal symbiont of the redbay ambrosia beetle causes a lethal wilt in redbay and other Lauraceae in the southeastern United States. Plant Dis. 92:215-224.

Fraedrich, S. W., Johnson, C. W., Menard, R. D., Harrington, T. C., Olatinwo, R., and Best, G. S. 2015a. First report of Xyleborus glabratus (Coleoptera: Curculionidae: Scolytinae) and laurel wilt in Louisiana, USA: the disease continues westward on sassafras. Fla. Entomol. 98:1266-1268.

Grünwald, N. J., Goodwin, S. B., Milgroom, M. G., and Fry, W. E. 2003. Analysis of genotypic diversity data for populations of microorganisms. Phytopathology 93:738-746.

Grünwald, N. J., and Hoheisel, G.-A. 2006. Hierarchical analysis of diversity, selfing, and genetic differentiation in populations of the oomycete Aphanomyces euteiches. Phytopathology 96:1134-1141.

Hanula, J. L., Mayfield, A. E., III, Fraedrich, S. W., and Rabaglia, R. J. 2008. Biology and host associations of the redbay ambrosia beetle (Coleoptera: Curculionidae: Scolytinae), exotic vector of laurel wilt killing redbay trees in the southeastern United States. J. Econ. Entomol. 101:1276-1286.

Harrington, T. C., Aghayeva, D. N., and Fraedrich, S. W. 2010. New combinations in Raffaelea, Ambrosiella, and Hyalorhinocladiella, and four new species from the redbay ambrosia beetle, Xyleborus glabratus. Mycotaxon 111:337-361.

Harrington, T. C., and Fraedrich, S. W. 2010. Quantification of propagules of the laurel wilt fungus and other mycangial fungi from the redbay ambrosia beetle, Xyleborus glabratus. Phytopathology 100:1118-1123.

Harrington, T. C., Fraedrich, S. W., and Aghayeva, D. N. 2008. Raffaelea lauricola, a new ambrosia beetle symbiont and pathogen on the Lauraceae. Mycotaxon 104:399-404.

Harrington, T. C., Yun, H. Y., Lu, S.-S., Goto, H., Aghayeva, D. N., and Fraedrich, S. W. 2011. Isolations from the redbay ambrosia beetle, Xyleborus glabratus, confirm that the laurel wilt pathogen, Raffaelea lauricola, originated in Asia. Mycologia 103:1028-1036.

Hughes, M. A., Black, A., and Smith, J. A. 2014. First report of laurel wilt caused by Raffaelea lauricola on bay laurel (Laurus nobilis) in the United States. Plant Dis. 98:1159.

Hughes, M. A., Brar, G., Ploetz, R. C., and Smith, J. A. 2013 Field and growth chamber inoculations demonstrate Persea indica as a newly recognized hos for the laurel wilt pathogen, Raffaelea lauricola. Plant Health Prog. doi: 10.1094/PHP-2013-0814-02-BR.

Hughes, M. A., Shin, K., Eickwort, J., and Smith, J. A. 2012. First report of laurel wilt disease caused by Raffaelea lauricola on silk bay in Florida. Plant Dis. 96: 910

Hughes, M. A., Smith, J. A., Mayfield, A. E., III, Minno, M. C., and Shin, K. 2011 First report of laurel wilt disease caused by Raffaelea lauricola on pondspice in Florida. Plant Dis. 95:1588.

Hughes, M. A., Smith, J. A., Ploetz, R. C., Kendra, P. E., Mayfield, A. E., III, Hanula, J. L., Hulcr, J., Stelinski, L. L., Cameron, S., Riggins, J. J., Carrillo, D., Rabaglia, R., Eickwort, J., and Pernas, T. 2015. Recovery plan for laurel wilt on redbay and other forest species caused by Raffaelea lauricola and disseminated by Xyleborus glabratus. Plant Health Prog. 16: 173-210.

Hulcr, J., and Lou, Q.-Z. 2013. The redbay ambrosia beetle (Coleoptera: Curculionidae) prefers Lauraceae in its native range: records from the Chinese National Insect Collection. Fla. Entomol. 96:1595-1596.

Jacobi, V., Dufour, J., Bouvet, G. F., Aoun, M., and Bernier, L. 2010 Identification of transcripts up-regulated in asexual and sexual fruiting bodies of the Dutch elm disease pathogen Ophiostoma novo-ulmi. Can. J. Microbiol. 56:697-705.

Kamvar, Z. N., Tabima, J. F., and Grünwald, N. J. 2014. Poppr: An R package for genetic analysis of populations with clonal, partially clonal, and/or sexual reproduction. PeerJ 2:e281.

Kano, R., Tsui, C. K.-M., Hamelin, R. C., Anzawa, K., Mochizuki, T., Nishimoto, K., Hiruma, M., Kamata, H., and Hasegawa, A. 2015. The MAT1-1: MAT1-2 ratio of Sporothrix globosa isolates in Japan. Mycopathologia 179:81-86. 
Kim, M.-S., Hohenlohe, P. A., Kim, K.-H., Seo, S.-T., and Klopfenstein, N. B. 2016. Genetic diversity and population structure of Raffaelea quercusmongolicae, a fungus associated with oak mortality in South Korea. For. Path. 46:164-167.

Kimura, M. 1983. The neutral theory of molecular evolution. Cambridge University Press, Cambridge.

Kirkendall, L. R., Kent, D. S., and Raffa, K. F. 1997. Interactions among males, females and off spring in bark and ambrosia beetles: the significance of living in tunnels for the evolution of social behavior. Pages 181-215 in: The evolution of social behavior in insects and arachnids. Choe, J. C., and Crespi, B. J., eds. Cambridge University Press, Cambridge.

Kück, U., and Pöggeler, S. 2009. Cryptic sex in fungi. Fungal Biol. Rev. 23:86-90.

Maner, M. L., Hanula, J. L., and Braman, S. K. 2013. Gallery productivity, emergence, and flight activity of the redbay ambrosia beetle (Coleoptera: Curculionidae: Scolytinae). Environ. Entomol. 42:642-647.

Mayfield, A. E., III, and Hanula, J. L. 2012. Effect of tree species and end seal on attractiveness and utility of cut bolts to the redbay ambrosia beetle and granulate ambrosia beetle (Coleoptera: Curculionidae: Scolytinae). J. Econ. Entomol. 105:461-470.

Mayfield, A. E., III, Smith, J. A., Hughes, M., and Dreaden, T. J. 2008. First report of laurel wilt disease caused by a Raffaelea sp. on avocado in Florida. Plant Dis. 92:976.

Maynard Smith, J., Smith, N. H., O'Rourke, M., and Spratt, B. G. 1993. How clonal are bacteria? Proc. Natl. Acad. Sci. USA 90:4384-4388.

Menard, R. D., Clarke, S. R., Fraedrich, S. W., and Harrington, T. C. 2016. First report of laurel wilt, caused by Raffaelea lauricola, on redbay (Persea borbonia) in Texas. Plant Dis. 100:1502.

Musvuugwa, T., de Beer, Z. W., Duong, T. A., Dreyer, L. L., Oberlander, K. C., and Roets, F. 2015. New species of Ophiostomatales from Scolytinae and Platypodinae beetles in the Cape Floristic Region, including the discovery of the sexual state of Raffaelea. Antonie van Leeuwenhoek 108:933-950.

Nei, M. 1987. Molecular evolutionary genetics. Columbia University Press, New York.

Olatinwo, R., Barton, C., Fraedrich, S., Johnson, W., and Hwang, J. 2016. First report of laurel wilt, caused by Raffaelea lauricola, on sassafras (Sassafras albidum) in Arkansas. Plant Dis. 100:2331-2331.

Oliveira, E. J., Pádua, J. G., Zucchi, M. I., Vencovsky, R., and Vieira, M. L. C. 2006. Origin, evolution and genome distribution of microsatellites. Genet. Mol. Biol. 29:294-307.

Paoletti, M., Buck, K. W., and Brasier, C. M. 2005. Cloning and sequence analysis of the MAT-B (MAT-2) genes from the three Dutch elm disease pathogens, Ophiostoma ulmi, O. novo-ulmi, and O. himal-ulmi. Mycol. Res. 109: 983-991.

Paoletti, M., Buck, K. W., and Brasier, C. M. 2006. Selective acquisition of novel mating type and vegetative incompatibility genes via interspecies gene transfer in the globally invading eukaryote Ophiostoma novo-ulmi. Mol. Ecol. 15: 249-262.

Ploetz, R. C., and Konkol, J. 2013. First report of gulf licaria, Licaria triandra, as a suscept of laurel wilt. Plant Dis. 97:1248.
Ploetz, R. C., Pérez-Martínez, J. M., Smith, J. A., Hughes, M., Dreaden, T. J., Inch, S. A., and Fu, Y. 2012. Responses of avocado to laurel wilt, caused by Raffaelea lauricola. Plant Pathol. 61:801-808.

Ploetz, R. C., Thant, Y. Y., Hughes, M. A., Dreaden, T. J., Konkol, J. L., Kyaw, A. T., Smith, J. A., and Harmon, C. L. 2016. Laurel wilt, caused by Raffaelea lauricola, is detected for the first time outside southeastern United States. Plant Dis. 100:2166-2166.

Rabaglia, R. J., Dole, S. A., and Cognato, A. I. 2006. Review of American Xyleborina (Coleoptera: Curculionidae: Scolytinae) occurring north of Mexico, with an illustrated key. Ann. Entomol. Soc. Am. 99:1034-1056.

Riggins, J. J., Fraedrich, S. W., and Harrington, T. C. 2011. First report of laurel wilt caused by Raffaelea lauricola on Sassafras in Mississippi. Plant Dis. 95: 1479.

Riggins, J. J., Hughes, M., Smith, J. A., Mayfield, A. E., III, Layton, B., Balbalian, C., and Campbell, R. 2010. First occurrence of laurel wilt disease caused by Raffaelea lauricola on redbay trees in Mississippi. Plant Dis. 94:634.

Simpson, M. C., Wilken, P. M., Coetzee, M. P. A., Wingfield, M. J., and Wingfield, B. D. 2013. Analysis of microsatellite markers in the genome of the plant pathogen Ceratocystis fimbriata. Fungal Biol. 117:545-555.

Smith, J. A., Dreaden, T. J., Mayfield, A. E., III, Boone, A., Fraedrich, S. W., and Bates, C. 2009a. First report of laurel wilt disease caused by Raffaelea lauricola on sassafras in Florida and South Carolina. Plant Dis. 93:1079.

Smith, J. A., Mount, L., Mayfield, A. E., III, Bates, C. A., Lamborn, W. A., and Fraedrich, S. W. 2009b. First report of laurel wilt disease caused by Raffaelea lauricola on camphor in Florida and Georgia. Plant Dis. 93:198.

Steimel, J., Engelbrecht, C. J., and Harrington, T. C. 2004. Development and characterization of microsatellite markers for the fungus Ceratocystis fimbriata. Mol. Ecol. Notes 4:215-218.

Stoddart, J. A., and Taylor, J. F. 1988. Genotypic diversity: estimation and prediction in samples. Genetics 118:705-711.

Swofford, D. L. 2002. PAUP* version 4.0 b10. Phylogenetic analysis using parsimony (* and other methods). Sinauer Associates, Sunderland, MA.

Takahashi, Y. S., Matsushita, N., and Hogetsu, T. 2015. Genotype distribution of Raffaelea quercivora in the oak galleries and its composition in the mycangia of Platypus quercivorus. For. Path. 45:149-154.

Teixeira, M. D. M., Rodrigues, A. M., Tsui, C. K. M., de Almeida, L. G. P., Van Diepeningen, A. D., van den Ende, B. G., Fernandes, G. F., Kano, R., Hamelin, R. C., Lopes-Bezerra, L. M., Vasconcelos, A. T. R., de Hoog, S., de Camargo, Z. P., and Felipe, M. S. S. 2015. Asexual propagation of a virulent clone complex in a human and feline outbreak of sporotrichosis. Eukaryot. Cell 14:158-169.

Tsui, C. K.-M., DiGuistini, S., Wang, Y., Feau, N., Dhillon, B., Bohlmann, J., and Hamelin, R. C. 2013. Unequal recombination and evolution of the mating type (MAT) loci in the pathogenic fungus Grosmannia clavigera and relatives. G3 Genes Genomes Genomics 3:465-480.

Wilken, P. M., Steenkamp, E. T., Hall, T. A., de Beer, Z. W., Wingfield, M. J., and Wingfield, B. D. 2012. Both mating types in the heterothallic fungus Ophiostoma quercus contain MAT1-1 and MAT1-2 genes. Fungal Biol. 116 427-437. 